\section{Research and the Cotton Industry}

THE actual results obtained in the scientific research carried out at the Shirley Institute are the property of the members subscribing and this undoubtedly handicaps the Association in propaganda work. Enough regarding the work, however, was revealed in general terms at the annual meeting to indicate the actual and potential value of the Institute to the industry. The staff has been in contact during the year with more than 90 per cent of the member firms. Results already obtained fully justify Mr. Greg's assertion that economy on research even in the days of bad trade is unwise and unprofitable, and that the Association is worthy of far more generous support by the industry. The number of problems already raised by members which cannot be attacked by the Institute is considerable and the diversion of effort from longrange or fundamental research to current trade problems is a serious threat to the future development and prosperity of the industry. These are matters in which the nation as a whole is vitally concerned, but it cannot be expected that the direct contribution of the State can be materially increased except pari passu with a fitting acceptance by the industry itself of its own financial responsibilities for research.

\section{Archrological Studies in Mexico}

A Decision of the Supreme Court of Mexico, it is reported by Science Service (Washington, D.C.), is expected during the current month, which is of considerable moment for the future study of the archæology of Central America. The point at issue is the control by individual States of the archæological sites within their respective boundaries. For some years the Central Government, largely owing to the influence of Señor Gamio, himself an archæologist of note, has displayed commendable energy in the examination and excavation of the archæological sites of the country. Any decision which would hamper or disturb the organisation of systematic exploration would be unfortunate in the extreme. The arrangements for the season now opening are already complete; but work cannot go forward until the decision of the courts is known. It may be hoped that whatever the verdict, some modus vivendi will be attained to satisfy both local interests and any claims the Central Government may justly put forward on the ground of its superior facilities for organised research.

THE archæological activities which are delayed pending decision are considerable. At Monte Alban, where the now famous gold treasure was discovered in a tomb this year, an appropriation three times as large as that of last year is to be expended in the further excavation of the innumerable tombs on the site ; while stratigraphical study is to be carried on with a view of correlation with Maya sites to the east, south and north. The exploration of a Zapotec fortress known as Quiengola, south of Monte Alban, is to be initiated ; and further explora- tions are to be made in the tomb at Texmelincan, the remote area of Guerrero, from which part only of the contents, including a number of gold objects, was removed at the time of its discovery early this year. In the important Toltec city of Teotihuacan, near Mexico City, the excavation of the "Avenue of the Dead", the mile-long central axis of the city with its row of mounds, now known to be the plat. forms of temples, is to be continued. At Chichen Itzá, which may be considered the strategic point for at least one period of Mayan history, important work on the interior of the pyramid of the Temple of Kukulkan, the Bird Snake, will be carried further. This pyramid, $90 \mathrm{ft}$. high, is the highest in the city, and in last season's excavation was found to enclose a smaller pyramid. It is intended this year to explore this contained pyramid and search for other internal structures. This outline of impending excavation, brief as it is, will indicate the extent of the interests involved in the forthcoming decision, quite apart from any questions which may arise affecting the position of the numerous expeditions from the United States now operating in Mexico.

\section{The Horniman Museum and Library}

THE late Mr. Emslie J. Horniman has bequeathed a sum of $£ 10,000$, free of duty, to the London County Council, for the purpose of providing an extension to the Horniman Museum, Forest Hill. The Museum was built by the late Mr. John E. Horniman, father of the testator, and before it was opened to the public he presented it and its contents, in 1901, to the London County Council. As is usual, and perhaps inevitable, in museums, the collections have since outgrown the accommodation, with the result that cases have become overcrowded, and progress has been hampered. This is more especially so with the collections dealing with the material culture of backward peoples. The provision of additional space will enable the present exhibited series to be opened out and extended, thus furthering that educational arrangement of the collections which has been the constant aim of the Museum authorities. It may be noted that Mr. Horniman's interest in the Museum has been shown in many ways, notably in the pro. vision, in 1912, of an extension for the purposes of a lecture hall and library.

UNDER Dr. H. S. Harrison, who was appointed curator in 1904, the collections have been built up continuously with the view of the function of the Museum as providing material for the study of the development of the arts and erafts of primitive races and the natural history of man and animals. The educational value of the Museum collections has been much enhanced by the excellent series of handbooks, prepared by the staff, which deal, in a scientific spirit, but in not too technical a manner, with the developmental aspect of the collections, illustrating such topics as fire-making, transport, tools from the stone age to the steel age, and the like. The enlightened policy of the education authority for London in promoting lectures on the

No. 3287, Vor. 1307 